\title{
UNIVERSITY BRANDING DURING COVID-19: A STUDY ON THE ROLE OF SOCIAL MEDIA IN PROMOTING COVID-19 AWARENESS AND BUILDING BRAND IMAGE
}

\author{
Soumen Bhattacharya \\ Research Scholar, Amity School of Communication, \\ Amity University Uttar Pradesh, Lucknow Campus, India \\ Dr. Mohammad Faisal \\ Assistant Professor, Amity School of Communication, Amity University Uttar Pradesh, \\ Lucknow Campus, India
}

\begin{abstract}
The aim of this study is to understand how digital platform especially social media is being used for branding purpose of higher education during the COVID-19 pandemic. During the present era, the traditional way of branding such as newspaper advertisement, radio jingles, career counseling workshops, education fairs, billboards has taken a back step. The Universities are implementing a unique method to create awareness about COVID-19 and for building up the brand image as part of the outreach program. Higher education especially during the COVID-19 Pandemic has started to use social media to get a competitive advantage. The present study will analyze and compare Facebook pages of the Maharishi University of Information Technology, Lucknow; Amity University Uttar Pradesh, Noida; Sharda University, Greater Noida, and Rama University, Kanpur from May-July 2020. The purposive sampling method was used to select the sample. The result of this study is divided into four different categories: a) The number of fans b) The posts related to COVID-19 awareness c) Content d) Like, Share \& Comment. On basis of this study, the selected posts could be used as an example in case studies for other Universities/Institutions to increase their reach and subsequently build a strong brand image.
\end{abstract}

Keywords: Universities, Facebook, Social Marketing, Social Media, COVID-19

\section{INTRODUCTION:}

The year 2020 has witnessed a startling change that was brought in with the turn in 2019 with the SARC-COV-2, also known as COVID-19 pandemic has affected the whole society and every sector, whether tourism, commerce or educational sector. But being one of the developing countries and with continuing digitization, the need for educated candidates and because of which increased demand for higher education has increased. This has also led the increased competition among the universities. In the run of being the best in the competition, the need for the online presence of the universities also arises, and also in the pandemic of COVID-19, the necessity of students to provide the education has increased the need for the online presence of the university and the services they offer to the potential students. In the era of the ecosystem of digital media, universities and higher education institutes are using digital media platforms for branding themselves (Shaifali Chauhan, 2019). Social media is one of the platforms that help in clouting young consumers and which are the main target for the universities and the higher education institutes (Ajzen, I., 2015) (Mumtaz, 2019). According to the research studies, social media plays an important role in the decision-making factor of the potential students for choosing higher education and universities (Babi'c, Ana, Francesca Sotgiu, Kristine de Valck, and Tammo H. A. Bijmolt, 2016).

According to the data available till July 2020, there are around 290 million Facebook users alone in India and making India one of the largest Facebook user countries after the United States (Bus. Horiz. 2011; Leninkumar, V., 2017). Among the number of users, the university target group customer varies from the age group of 18-25 years, which are the most active users among them all with the average no. of 97.2 million users (DeAndrea, D.C.; Ellison, N.B.; LaRose, R.; Steinfield, C.; Fiore, A., 2012; 2018). According to the statistics available, Social Media is used by 
university students on a daily basis. Most of the students use Facebook as one of the Social Media platforms to connect with their peers and friends (Crawford, J., Butler-Henderson, K., Rudolph, J., Malkawi, B., Glowatz, M., Burton, R., . . . Lam, S., 2020). Facebook has come up as one of the important social media platforms for the prospective students to search related to their universities and building an ever-ending relationship with the environment they are stepping into (DeAndrea, D.C.; Ellison, N.B.; LaRose, R.; Steinfield, C.; Fiore, A., 2012). According to the research from the different scholars have made a perpetual attempt to classify social media and to understand their marketing aspects (DeAndrea, D.C.; Ellison, N.B.; LaRose, R.; Steinfield, C.; Fiore, A., 2012).

With the impact of COVID-19 all over the globe, it has changed the way the educational sector. The branding of the universities and higher education institutions was done on both the way that is traditional and digital marketing but after the COVID-19 outbreak, the branding of the educational sector has moved more to the digital media platform (Ellison, N.B.; Steinfield, C.; Lampe, C., 2011, 2013). The Uttar Pradesh Universities doesn't get an exemption from the pandemic caused by the COVID-19 and the lockdown that happen from March 2020 has made the branding of universities and educational institutes to an online platform, especially to Facebook marketing.

Therefore, universities and higher education institutes have selected Facebook as one of the mediums through which they can reinforce their brand performance and brand awareness in the prospective students and could ensure their survival and success during this pandemic crisis.

University branding with the use of social media is one of the marketing tools, which will encourage and promote the image of the university and higher education institutions during this competitive era. Therefore, the current research will try to explain how the Universities in Uttar Pradesh will try to gain over competitors in this COVID-19 pandemic. The COVID-19 crisis has a proportionate effect on customer satisfaction and customer loyalty and has also modified the way the people are doing things and has changed the way they view a particular thing. Factors like consumer trust, perception, behavior, and attitude have been altered by this COVID-19 crisis, this has led the customers less buoyant about the trust factor among the brand. This has not kept the students unaffected by the crisis, as their studies, their planning, and another schedule has been hampered because of the pandemic. For this, the University has the challenges to attain customer brand loyalty, brand satisfaction, and brand trust without physical interactions. Therefore, keeping all these needs of the customers/students through the online platform of Facebook (Vithya Leninkumar, 2017). In this way social media platforms especially, Facebook has endowed the university and higher education institution for brand performance, customer satisfaction, and brand loyalty. Among all these customer satisfactions is the preliminary factor for the success of the brand performance of the universities (González-Mansilla, Ó., Berenguer-Contrí, G., \& Serra-Cantallops, A., 2019). Universities are following the different strategies of branding through the social media platforms which keep the university in interaction with the customers/students and can maintain the trust of the students towards them. Another factor that is responsible for building trust among the among is the service quality which can be portrayed through Facebook and in return students can view the service quality and facility provided to them and will enhance brand performance and brand image (González-Mansilla, Ó., Berenguer-Contrí, G., \& Serra-Cantallops, A., 2019).

\section{LITERATURE REVIEW}

The study focuses on the universities and higher education institution and their presence and performance on social media. The universities and higher education institutions pursue to provide benefits to their stakeholders in terms of students, prospective students, parents, and faculty members. So, for the universities and higher education institutions, it becomes important that they use different strategies to analyze their performance to reach a greater number of stakeholders and create a unified brand image. In the era of globalization, many universities and higher education institutions are using Information Communication Technology (ICT), to build their brand image and to 
provide the perceived service quality to the stakeholders.

\section{Use of Interactive method with Facebook to keep the engagement with the students:}

In the amid of the COVID-19 outbreak, Social Media, especially Facebook is helping the universities and the higher education institution in formulating the standard of providing the perceived service quality to the university and higher education institutions. As to maintain the equilibrium of service quality offered to the students as well as stakeholders and building their brand image among the target group (Vinod Bhatt, 2018). Facebook benefits the university and higher education institution towards the main aim of the universities that to provide the student's satisfaction in terms of their interest, connecting them with their university and higher education institutions during the crisis and show them the concern that university and higher education institutions care for their interest and the services associated with them and fulfilling their expectations from the university and higher education institutions.

From the "theory of Planned behavior," the theory suggests that for building the brand the universities and higher education also need to work for the external environment of the customers, as their attitude, their behavior, and their interest towards the engagement that is created by the universities and higher education institutions from the Facebook page (Ajzen, I., 2015). This also somehow insures that when the students are following their university or higher education institution pages they are keeping in mind that their university and higher education institutions will be providing them the updated knowledge about the happenings in the university and also working hard to provide them insights of their interest, this will in return universities and higher education institutions will get more engagement and fan following and increased satisfaction with the Facebook page.

One of the researches conducted states that the use of social media for attracting the users with engaging activities will enhance their skills, learning can be improved, and can have more fan base (Elena, D.-B., \& Jose, L. M.-A., 2001). And also, the marketing strategy of engaging more users will also increase student satisfaction (Endres, M. L., Chowdhury, S., Frye, C., \& Hurtubis, C. A., 2009) and to increase more and more students to the universities and higher education institutions page (Manochehri, N. N., \& Young, J. I., 2006), (Mitić, S., Nikolić, M., Jankov, J., Vukonjanski, J., \& Terek, E., 2017), (Gray, J. A., \& DiLoreto, M., 2016).

The Content posted by Universities and Higher Education Institutions on Facebook:

With the use of UGC (User Generated Content) and also the different content created by the universities and higher education institutions which can be the content regarding the information that sounds the students about the new services, changes, promotions and other universities related information which will generate more awareness about the university and higher education institutions (Pauwels, Koen, Zeynep Aksehirli, and Andrew Lackman., 2016). The customer/student attitude measures the brand performance which the universities and higher education institutions have placed in terms of the content they have created and the customer attitude is the opinion which is gathered in terms of like, comment and views on the particular post done by the universities and higher education institutions and will ensure developing trust among the students for the brands (Hanna, R.; Rohm, A.; Crittenden, V.L., 2011). Other than this, the student's satisfaction towards a particular brand can be developed if the student's query and complaints are effectively and efficiently handled. A study revealed that around $75 \%$ of students feel more appreciated if they get the response to their query or complaint and this will lead to the recommendation of the brand to their friends, peers, and relatives and this will lead to WOM, which is one of the major tools of creating brand awareness (GonzálezMansilla, Ó., Berenguer-Contrí, G., \& SerraCantallops, A., 2019). This way Facebook will help in value-co-creation and enhanced students' engagement (NA, 2001) and also give the benefit to the universities and higher education institutions to develop their content in accordance with the students and can have two-way communication opportunity (Arnould, Eric J., Hope Jensen Schau, and Albert M. Muniz Jr., 2009).

The use of Social Media can also amplify the brand image with the use of the new 
technologies, such as VR (Virtual Reality) and AR (Augmented Reality) which help the users to see the infotainment post and also with the use of motion sensor they can interact with the object and feel like they are the part of the post (Laurell, C.; Sandström, C.; Berthold, A.; Larsson, D., 2019). This is the new way of content posted on social media platforms. Also, the use of Chatbots, which is the help desk that helps the user to get answers for their query and complaints.

The importance of Likes, Share, and Comments for the Universities and Higher Education Institutions:

The studies previously conducted argue about the importance of the "Likes, "Share" and "Comment" on the universities and higher education institutions posted on the Facebook page. The demeanor related with the "Likes", "Share" and "Comment" could be positive or negative in nature related to the sentiments which the student have for the particular post and the same could influence the other customers whether they are already the students or the prospective students of the university and higher education institutions (Babi'c, Ana, Francesca Sotgiu, Kristine de Valck, and Tammo H. A. Bijmolt., 2016) and (Goh, Khim Yong, Cheng-Suang Heng, and Zhijie Lin., 2013).

There have been many pieces of research in the past which validate that the use of Social media that has a positive or negative effect on the psyche of the students and that can be distributed further as an E-WOM (Electronic Word of Mouth that has a direct percussion on the brand value and brand image of the universities and the higher education institutions (Pauwels, Koen, Zeynep Aksehirli, and Andrew Lackman, 2016). The "Like", "share" and "Comments" received in the post can be converted as a lead for universities or higher education institutions (Saura, José Ramón, Pedro Palos-Sánchez, and Luis Manuel Cerdá Suárez., 2017). This can lead the students to enquire about the brand, show their interest by asking for the brochure to gather more information about the brand. This will increase the brand image and the brand awareness of the universities and the higher education institution and can shift the student's perception and changing towards positive brand attitudes (Crawford, J., Butler-
Henderson, K., Rudolph, J., Malkawi, B., Glowatz, M., Burton, R., . . . Lam, S., 2020).

The use of Paid Promotions for reaching more target groups of stakeholders through Facebook:

The organic reach of every post is reduced by Facebook, so it becomes imperative for the universities and higher education institutions to opt for paid promotion for the posts they want higher reach and more target audience. According to the universities and higher education institute market themselves to achieve the higher target customer and to create more brand loyalty (Jane HemsleyBrown, Izhar Oplatka, 2006). The universities and higher education institutions work on a model of "Collaborative Relationships" that is when the content or post is posted on social media that will generate results only when the post is viewed by the right segment of the target audience (Priya Handa, 2018) (Vinod Bhatt, 2018). In the other studies, the use of relationship marketing by using the promotional post on the Facebook pages will yield appropriate results (Helgesen, 2008; Klassen, 2002). With the use of relationship marketing and the promotional page created for that purpose, the universities and the higher education institutions can recall their loyal base of customers such as alumni, present students, and also prospective students (Helgesen, 2008; Klassen, 2002).

The current study analyses different aspects of university branding during the outbreak of COVID-19 and its impact on the university and higher education institution branding in Uttar Pradesh, India. The related research question scrutinized in the study are as follows:

RQ1. The number of Fan base/the way they interact with the users and the different strategies they formulate to keep their audience and visitors engaged.

RQ2. The type of content they post on their Facebook and the result they get.

RQ3. The content posted on Facebook about COVID-19 and the awareness created about it.

RQ4. The reaction, share, and comment the universities received for their post.

The present study is divided into four different sections. The first section establishes the context of the study followed by the 
second section which examines the different literature available from the different studies conducted on the related field across the globe. The third section of the study deals with the methodology used in analyzing the research data gathered for the study. The next section will be discussing the research findings gathered through the data and accomplishment of the research questions examined in the study and at last, the last section will give the conclusion driven from the results and findings and will provide future guidance and limitation of the study.

\section{METHODOLOGY}

This section of the research paper will examine the different data used for the study and the choice of the universities and the method to analyze the data gathered from those universities and higher education institutions.

\section{RESEARCH DESIGN}

The purpose of the research is to examine and to compare the Facebook pages and Content created by the selected five universities of Uttar Pradesh. The purposive sampling technique will be used to monitor the post which is published, the content of the post, engagement created with the post, and the proportionate number of post that are having paid promotion. The research will be conducted by scrutinizing the Facebook of four selected Universities.

Tool used:

Content Analysis is a research method used to identify pattern in recorded communication (LUO.A,2020). The post was categorized by the researcher and were used to analyze.

Table- 01

\begin{tabular}{|l|c|}
\hline University & Facebook Fans \\
\hline $\begin{array}{l}\text { Maharishi University of } \\
\text { Information Technology }\end{array}$ & 20,672 \\
\hline $\begin{array}{l}\text { Amity University Uttar } \\
\text { Pradesh }\end{array}$ & $2,007,451$ \\
\hline Sharda University & $1,139,237$ \\
\hline Rama University & 83,317 \\
\hline
\end{tabular}

Source: Facebook pages of the respective Universities

From the above table, it is clear that Amity University Uttar Pradesh has the maximum number of Facebook Fans.

Table- 02

\begin{tabular}{|l|c|c|c|c|c|}
\hline University & Reactions & Comments & Shares & MEPT & Fans \\
\hline $\begin{array}{l}\text { Maharishi University of Information } \\
\text { Technology }\end{array}$ & 515 & 16 & 59 & Photo & 20,672 \\
\hline Amity University Uttar Pradesh & 3556 & 244 & 664 & Video & $2,007,451$ \\
\hline Sharda University & 3406 & 453 & 555 & Photo & $1,139,237$ \\
\hline Rama University & 3650 & 509 & 435 & Video & 83,317 \\
\hline
\end{tabular}

Source: Author's calculation based on Facebook data, MEPT = Most Engaging Post Type. The posts were divided into categories. Each category Like, Comment $\mathcal{E}$ Share was added. The most engaging post (Highest number of engagement) content (video/ photo) was noted.

Facebook pages of data collected from selected universities. The investigation of the data which comprises of the content posted and how they are creating the students' and stakeholder's engagement with the selected universities and higher education institutions (Kashif Hasan, 2017).

\section{SAMPLE AND DATA COLLECTION}

The Universities are selected based on Purposive sampling based upon the year of establishment. The main basis of research comprises the accumulated number of fans the university or higher education institutions have on their Facebook page, the origin for the
From the above table, we can say that Amity University Uttar Pradesh, Sharda University \& Rama University post gets an average of 39 to 45 reactions. Since the number of posts in the case of the Maharishi University of Information Technology is low when compared to the other three Universities, the reaction or engagement is also low. In the case of Rama University \& Amity University Uttar Pradesh, video is the most engaging post type while Photograph is the most engaging post type in the case of the Maharishi University of Information Technology and Sharda University. 
Table- 03

Rama University

\begin{tabular}{|l|c|c|c|c|}
\hline Category & No. of Posts & Reactions & Comments & Shares \\
\hline Admissions & 29 & 252 & 20 & 5 \\
\hline Greetings & 05 & 162 & 50 & 72 \\
\hline Academic Activities & 31 & 70 & 0 & 8 \\
\hline Education 4.0 & 05 & 474 & 99 & 95 \\
\hline Contest & 09 & 2350 & 180 & 240 \\
\hline Corona Awareness & 11 & 342 & 86 & 15 \\
\hline
\end{tabular}

Source: Author's calculation based on Facebook data. The posts were divided into categories. Each category Like, Comment \& Share was added.

From the above table, it can be concluded that Contest posts had the maximum impact on the fans with over 2350 reactions on the Facebook page. These posts encourage the target audience to interact and showcase their talent with a larger group of audience. Greetings post like Mother's Day etc. got a smaller number of reactions but good comments and shares. The University focused on awareness of the general audience regarding COVID with 11 posts, 342 reactions, and 86 comments. The University focused more on scholarship and admission related posts. The University boasts of the variety of articles published on the website with a link on the Facebook post.

The University has used the same creative multiple times which may be due to the popularity of such posts. corona awareness. The University published 02 contest posts that had a good number of post reactions (377) and 77 shares. These posts were quite engaging. Fans were more inclined towards industry-centric content.

The University Facebook page had 0 posts related to Admissions, Greetings, and Corona awareness. The reason for this may be that the University is using other social media platforms to reach its target audience.

The University is not very active on social media (Facebook). The University has posted only 25 posts in the given timeframe of three months (May- July 2020). There were no posts related to Admissions, the posts related to the academic activities such as 'LIVE CODING SESSION ON 23.06.2020' had the major

Table- 04

Amity University

\begin{tabular}{|c|c|c|c|c|}
\hline Category & No. of Posts & Reactions & Comments & Shares \\
\hline Admissions & 0 & 0 & 0 & 0 \\
\hline Greetings & 0 & 0 & 0 & 0 \\
\hline Academic Activities & 31 & 3100 & 202 & 478 \\
\hline Education 4.0 & 01 & 79 & 20 & 109 \\
\hline Contest & 02 & 377 & 22 & 77 \\
\hline Corona Awareness & 0 & 0 & 0 & 0 \\
\hline
\end{tabular}

Source: Author's calculation based on Facebook data. The posts were divided into categories. Each category Like, Comment \& Share was added.

From the above table, it can be concluded that posts related to academic activities were highest in number. The total number of such posts was 31. It also has a maximum number of reactions i.e. 3100 . The posts were related to a variety of webinars wherein multiple creatives were uploaded in a single post. The number of comments (202) and shares (478) also sets a different example. There were no posts related to admissions, greetings, and interaction. The contest category post didn't give any boost to the University profile. There were 01 posts in the category of corona awareness. The University also greeted the audience on special occasions. Posts like 'Enhance your skills gear up yourself with innovative ideas and Excel with full enthusiasm in Real life experiment...' in the category of Education 4.0 had good shares when compared to other categories. 
Table- 05

Maharishi University

\begin{tabular}{|l|c|c|c|c|}
\hline Category & No. of Posts & Reactions & Comments & Shares \\
\hline Admissions & 0 & 0 & 0 & 0 \\
\hline Greetings & 6 & 86 & 2 & 0 \\
\hline Academic Activities & 12 & 357 & 10 & 36 \\
\hline Education 4.0 & 05 & 9 & 1 & 11 \\
\hline Contest & 01 & 11 & 0 & 0 \\
\hline Corona Awareness & 01 & 52 & 3 & 12 \\
\hline
\end{tabular}

Source: Author's calculation based on Facebook data. The posts were divided into categories. Each category Like, Comment \& Share was added.

On analysis of different categories, it was found that posts related to academic activities have a maximum number of interactions.
The reason for this might be the overburden of posts related to corona on different media platforms. The University also posted feeds

Table- 06

Sharda University

\begin{tabular}{|l|c|c|c|c|}
\hline Category & No. of Posts & Reactions & Comments & Shares \\
\hline Admissions & 90 & 14 & 0 & 0 \\
\hline Greetings & 10 & 99 & 3 & 29 \\
\hline Academic Activities & 48 & 1022 & 234 & 33 \\
\hline Education 4.0 & 154 & 1589 & 123 & 85 \\
\hline Contest & 8 & 111 & 54 & 106 \\
\hline Corona Awareness & 17 & 36 & 4 & 5 \\
\hline Supports Government & 18 & 99 & 89 & 3 \\
\hline Branding & 159 & 38 & 2 & 0 \\
\hline Testimonials & 59 & 398 & 0 & 174 \\
\hline
\end{tabular}

Source: Author's calculation based on Facebook data. The posts were divided into categories. Each category Like, Comment \& Share was added.

From the above table, it can be concluded that posts related to Branding and Education 4.0 were more in number as compared to other posts. There are 90 posts related to admissions, 59 posts were related to student and alumni testimonials, 48 posts were related to academic activities, 18 posts supported government initiatives, 10 posts were greetings and 08 posts were related to the online contest.

On analysis of the different categories of posts, it was found that the branding posts didn't attract much interaction i.e. Like, Comment \& Share. On the other hand, the Education 4.0 posts had maximum reactions (1589). The reason for the same could be the Fans are more interested in getting the latest information regarding the latest development in different fields. One of the striking features were posts related to Corona awareness, although the interaction on this post was not encouraging. related to the Indian Army. For example'Salute to all the brave soldiers of Indian Armed Forces who laid down their lives fighting for our nation'.

The University also highlighted the fact related to the number of female students on the campus. Thus, prolificating the idea of women empowerment and gender equality 'Female students make up about $40 \%$ of total student enrollment (about 13000+ students on Campus) at Sharda University making it one of the most preferred universities in Delhi NCR'.

The category of posts related to the contest had the highest share. The reason for this might be the interest of students to highlight their talents. A good number of posts (90) were related to the admission process. There was no sharing on these posts. The posts 
related to academic activities saw a balanced response/ interaction from the fans.

\section{Managerial Implications}

The focus of the universities by doing the posting of different kinds are for building brand equity by creating a positive brand image of the organization. The process of Image Building among the target group of the audience can be achieved by the web 2.0 methods of UGC (User Generated Content).

\section{Limitations of the study}

In-depth interview was not possible due to pandemic. Only four Universities were selected for the study due to time constraint.

\section{Future Scope}

The study could be replicated, and top twentyfive or fifty University Website/ Facebook pages can be analyzed to know in detail and the result could be generalized.

\section{DISCUSSION AND CONCLUSION}

Social media is one of the communication platforms that provide the feedback data about the behavior of the students and the stakeholders that are related to the university effectiveness related to the promotional campaigns run in social media platforms. It is necessary that the appropriate marketing strategy should be analysed and effectively used, for this the marketer should be steadily kept on evaluating and scrutinizing by collecting the available data through the social media platforms and to acquire the insights. Nowadays, social media has come as a boom for the universities for posting the news, feeds, and promotional features on the pages. This also enables the university to also to know which post, promotion, and feed are giving their best performances and could also monitor the research area of the students or their success status as an individual.

Another way of targeting the viewers and audiences are posting of the universities for paying the tributes to the renowned person and the researchers and scientists of the world. The main focus of the universities by doing the posting of different kinds are for building brand equity by creating a positive brand image of the organization. The process of Image Building among the target group of the audience can be achieved by the web 2.0 methods of UGC (User Generated Content). It is achieved through different contest and eWOM (electronic word of mouth) and by these universities also try to facilitate their students and stakeholders about their transparency in communicating with their targets and in their university style of working. It is difficult for the university to assert the use of social media for maintaining transparency, openness in the communication process that takes place between the university and the students, whether current or prospective students. Still, after having the complex task by the university in handling the social media, the platform also proves to be effective enough for influencing the decision-making process of the current and prospective users by effectively using the communication strategy by the university. This will also help the universities in gaining the opportunity above the competitors instead of being a big brand or already a named brand in the market. On average university work on one piece of news feed or any content per day. As the University is the oldest university among all listed universities or higher education institutions, their listing also shows the tradition and the major achievement of the universities in the context of students and stakeholders. The University is dependent on the testimonial which the university has gathered and the reviews which are collected from more than students' reviews and feedback.

Among all the social media platforms Facebook is one of the platforms, where the reviewer can rate the page according to the services provided, post posted and this also enables the owner of the page to reply or respond to the reviews and feedback that are received on the page and other than that the students can other than rating can interact, comment on the information given on the Facebook page.

The University, take the initiative for managing the new students who are coming to the university and making them aware of the happening in the university and has come up as one their marketing strategy for students to accumulate to the new place and new environment.

As the study has different limitations, the focus of the researcher on getting the detailed analysis of the single social media platform, so to keep the findings consistent and same with the other studies done on the same ground. 
The researcher obtained the different behavior of social media and also, the engagement created by the social media platform for the different universities.

The research done is neither accepted nor rejected in the study conducted as the selection of the universities is done on the distinct subject they choose to be taught. It is also identifying in the study that the post that is having more images/ pictures are recognized more and also create greater engagement. The finding also proves that the image is more feasible in drawing students and stakeholder's attention rather than only text or the contents in the post. Finally, it can be proclaimed that the equivalent engagement can be generated by the total number of posts posted by the university than those whose post is low in frequency.

According to Peruta (2017) found an interesting disparity among the number of fans and the followers on the social media platform as per their individual engagements. It can be concluded that traditional universities could have a huge number of followings, but the engagement of the students and stakeholders is comparatively less. Also, it is also establishing that the frequent posting and lower frequency that is posting on the huge number and posting on a very less number also have a negative impact on the universities creating the engagement. The researcher suggests that this can create a negatively correlated for the higher following and the frequency by which the post is posted on the page.

Our study suggests a negative correlation of an increase in following and an increase in posting frequency. This finding is in keeping with the results of Eyrich et al., who argue that quality is a major factor determining the success of social media. It is also suggested that the universities should design the higherquality post that should convey the right information and also in an attractive manner, whereas, the poor quality of the information disseminated to the users can be negative impact for the university, this can also be one of the factors from the establishment of the university to the time taken to be part of the social media platform. The findings from the study suggest that it is not always necessary that the promotional campaign run by the universities or branding or rebranding the universities cannot always be fruitful as boosted by social media, Hilde et.al.. However, the study will always be opened for the discussions for the challenges faced by the universities.

\section{REFERENCES}

Ajzen, I. (2015). Consumer attitudes and behavior: the theory of planned behavior applied to food consumption decisions. Italian Review of Agricultural Economics, 70(2), 121-138.

Arnould, Eric J., Hope Jensen Schau, and Albert M. Muniz Jr. 2009. How Brand Communities Create Value. Journal of Marketing 73: 30-51

Babi'c, Ana, Francesca Sotgiu, Kristine de Valck, and Tammo H. A. Bijmolt. 2016. The Effect of Electronic Word of Mouth on Sales: A Meta-Analytic Review of Platform, Product, and Metric Factors. Journal of Marketing Research 53: 297-318. [CrossRef] Baltagi, Badi H. 2013. Econometric Analysis of Panel

Brech, F.M.; Messer, U.; Vander Schee, B.A.; Rauschnabel, P.A.; Ivens, B.S. Engaging fans and the community in social media: Interaction with institutions of higher education on Facebook. J. Mark. High. Educ. 2017, 27, 112-130. [CrossRef]

Constantinides, E.; Stagno, M.C.Z. Potential of the social media as instruments of higher education marketing: A segmentation study. J. Mark. High. Educ. 2011, 21, 7-24. [CrossRef]

Crawford, J., Butler-Henderson, K., Rudolph, J., Malkawi, B., Glowatz, M., Burton, R., . . . Lam, S. (2020). COVID-19: 20 countries' higher education intra-period digital pedagogy responses. Journal of Applied Learning \& Teaching, 3(1), 1-20.

Duan, Wenjing, Bin Gu, and Andrew B. Whinston. 2008. The Dynamics of Online Word-of-Mouth and Product Sales-An Empirical Investigation of the Movie Industry. Journal of Retailing 84: 233-42. [CrossRef]

Ellison, N.B.; Steinfield, C.; Lampe, C. Connection strategies: Social capital implications of Facebook-enabled 
communication practices. New Media Soc. 2011, 13, 873-892. [CrossRef]

Elena, D.-B., \& Jose, L. M.-A. (2001). Brand trust in the context of consumer loyalty. 35(11-12), 1238-1258.

Endres, M. L., Chowdhury, S., Frye, C., \& Hurtubis, C. A. (2009). The multifaceted nature of online MBA student satisfaction and impacts on behavioral intentions. Journal of Education for Business, 84(5), 304-312.

Ghobehei, M., Sadeghvaziri, F., Ebrahimi, E., \& Bakeshloo, K. A. (2019). The effects of perceived brand orientation and perceived service quality in the higher education sector. Eurasian Business Review, 9(3), 347-365.

. Gray, J. A., \& DiLoreto, M. (2016). The effects of student engagement, student satisfaction, and perceived learning in online learning environments. International Journal of Educational Leadership Preparation, 11(1), 1-20.

González-Mansilla, Ó., Berenguer-Contrí, G., \& Serra-Cantallops, A. (2019). The impact of value co-creation on hotel brand equity and customer satisfaction. Tourism Management, 75, 51-65. Goh, Khim Yong, Cheng-Suang Heng, and Zhijie Lin. 2013. Social Media Brand Community and Consumer Behavior: Quantifying the Relative Impact of User-and MarketerGenerated Content. Information Systems Research 24: 88-107. [CrossRef]

Goh, Khim Yong, Cheng-Suang Heng, and Zhijie Lin. 2013. Social Media Brand Community and Consumer Behavior: Quantifying the Relative Impact of Userand Marketer-Generated Content. Information Systems Research 24: 88-107. [CrossRef].

Hanna, R.; Rohm, A.; Crittenden, V.L. We're all connected: The power of the social media ecosystem. Bus. Horiz. 2011, 54, 265-273. [CrossRef] . Leninkumar, V. (2017). The relationship between customer satisfaction and customer trust on customer loyalty. International Journal of Academic Research in Business and Social Sciences, 7(4), 450-465.

Leading countries based on Facebook audience size as of July 2020(in millions) https://www.statista.com/statistics/2681 36/top-15-countries-based-on-number-offacebook-users/. . Leninkumar, V. (2017).

The relationship between customer satisfaction and customer trust on customer loyalty. International Journal of Academic Research in Business and Social Sciences, 7(4), 450-465.

Laurell, C.; Sandström, C.; Berthold, A.; Larsson, D. Exploring barriers to adoption of Virtual Reality through Social Media Analytics and Machine Learning-An assessment of technology, network, price and trialability. J. Bus. Res. 2019, 100, 469474. [CrossRef]

Marketing for Higher Education: A Relationship Marketing Approach (Helgesen, 2008; Klassen,2002.

Manochehri, N. N., \& Young, J. I. (2006). The impact of student learning styles with web-based learning or instructor-based learning on student knowledge and satisfaction. Quarterly Review of Distance Education, 7(3), 313-316.

Mitić, S., Nikolić, M., Jankov, J., Vukonjanski, J., \& Terek, E. (2017). The impact of information technologies on communication satisfaction and organizational learning in companies in Serbia. Computers in Human Behavior, 76, 87-101

Muniz, Albert M., Jr., and Thomas C. O'Guinn. 2001. Brand Community. Journal of Consumer Research 27: 412-32. [CrossRef]

. Number of Facebook users across India as of January 2018, by age and gender(in millions) https://www.statista.com/statistics/ 717615/india-number-of-facebook-users-byage-and-gender/

Pauwels, Koen, Zeynep Aksehirli, and Andrew Lackman. 2016. Like the Ad or the Brand? Marketing Stimulates Different Electronic Word-of-Mouth Content to Drive Online and Offline Performance. International Journal of Research in Marketing 33: 639-55. [CrossRef]

- Risius, Marten, and Roman Beck. 2015. Effectiveness of Corporate Social Media Activities to Increase Relational Outcomes. Information \& Management 52: 824-39. 
Saura, José Ramón, Pedro Palos-Sánchez, and Luis Manuel Cerdá Suárez. 2017. Understanding the Digital Marketing Environment with KPIs and Web Analytics. Future Internet 9: 76. [CrossRef]

Serious social media: On the use of social media for improving students' adjustment to college. Internet High. Educ. 2012, 15, 15-23. . DeAndrea, D.C.; Ellison, N.B.; LaRose, R.; Steinfield, C.; Fiore, A. [CrossRef]

Social media statistics in India https://www.talkwalker.com/blog/social -media-statistics-in-

india\#: : text=Facebook\%20Stats\%20in $\% 20$ India\&text $=$ The $\%$ 20largest $\%$ 20user $\% 20$ gro up $\% 20$ by,followed $\% 20$ by $\% 20$ Delhi $\% 20$ an d\%20Bengaluru

https://www.researchgate.net/publication/3 0930521_Universities_in_a_competitive_gl obal_marketplace_a_systematic_review_of _the_literature_on_higher_education_mar keting

Universal McCann. 2013. Cracking the Social Code: The Story of Why. Available online: http://wave.umww.

com/assets/pdf/wave_7-cracking-thesocial-code.pdf (accessed on 25 June 2018).
University Experiences, The Student-College Relationship, and Alumni Support May 2001Journal of Marketing for HIGHER EDUCATION 10(3):21-44

DOI: 10.1300/J050v10n03_02

https://www.researchgate.net/publication/3 0930521_Universities_in_a_competitive_gl obal_marketplace_a_systematic_review_of _the_literature_on_higher_education_mar keting (Shaifali Chauhan, 2019)

Anjani Kumar Srivastava, M. J. (2019, June). Status of Communicating CSR to Stakeholders on Social MediaA Case Study on ITC Limited \& Nestle India. Journal of Content, Community \& Communication, pp. 81-92.

Kashif Hasan, S. M. (2017, July). Political Campaign In The Era Of Internet: Politics Of Like, Comment And Share In Bihar Election 2015. International Journal of Innovative Research and Advanced Studies, pp. 170-175.

Mumtaz, R. (2019, December). Awareness and Perspectives Social Media as New Strategic Marketing Approach. Journal of Content, Community \& Communication, pp. 213-224. 